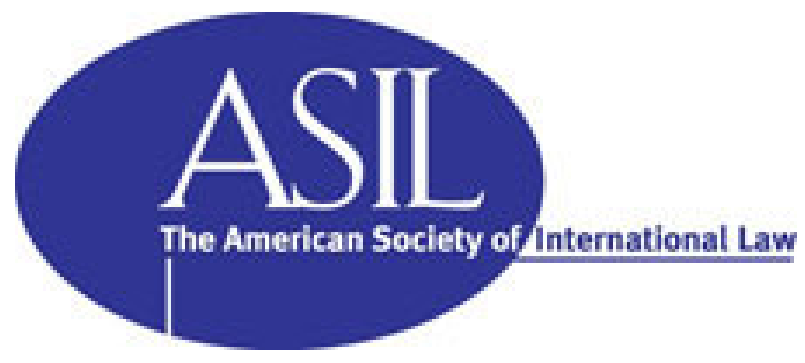

\author{
Australian Refugee Protection in the Wake of the Tampa \\ Author(s): Penelope Mathew \\ Source: The American Journal of International Law, Vol. 96, No. 3 (Jul., 2002), pp. 661-676 \\ Published by: American Society of International Law \\ Stable URL: http://www.jstor.org/stable/3062169
}

Accessed: 29/06/2009 00:42

Your use of the JSTOR archive indicates your acceptance of JSTOR's Terms and Conditions of Use, available at http://www.jstor.org/page/info/about/policies/terms.jsp. JSTOR's Terms and Conditions of Use provides, in part, that unless you have obtained prior permission, you may not download an entire issue of a journal or multiple copies of articles, and you may use content in the JSTOR archive only for your personal, non-commercial use.

Please contact the publisher regarding any further use of this work. Publisher contact information may be obtained at http://www.jstor.org/action/showPublisher?publisherCode=asil.

Each copy of any part of a JSTOR transmission must contain the same copyright notice that appears on the screen or printed page of such transmission.

JSTOR is a not-for-profit organization founded in 1995 to build trusted digital archives for scholarship. We work with the scholarly community to preserve their work and the materials they rely upon, and to build a common research platform that promotes the discovery and use of these resources. For more information about JSTOR, please contact support@jstor.org. 


\section{Australian Refugee Protection In the WAKE OF THE TAMPA}

September 11, 2001, marked the beginning of a new and frightening era. In Australia, the events of that tragic day created a climate receptive to radically altering national refugee law. Hoping that other countries might accept asylum seekers who had arrived within its waters, Australia adopted a scheme to farm out asylum seekers to Pacific islands for the processing of their claims. This scheme was audaciously, indeed, somewhat contemptuously, named "the Pacific Solution.” After setting out the relevant background, namely, the arrival in Australian waters of rescued asylum seekers on board the Norwegian freighter MV Tampa, this essay describes the legislative bases of the Pacific Solution and critiques the legislation in light of Australia's international obligations.

\section{FROM THE TAMPA TO THE NEW LEGISLATION}

On Sunday, August 26, 2001, the MV Tampa rescued 433 boat people from the Indian Ocean. The ship had been en route from Fremantle (in Australia) to Singapore, when Capt. Arne Rinnan diverted from his course in response to a call from the Australian Coast Watch. After asking the Australian authorities where he should take the rescued people and receiving an unhelpful "don't know" for an answer, the captain headed for Indonesia. He was pressured into changing course for the Australian territory of Christmas Island by five of his passengers, who had threatened to commit suicide. However, the Australian authorities ordered the ship to stop just outside Australian territorial waters off the coast of Christmas Island.

Captain Rinnan alerted Australian officials to the scarcity of food and water on board. On Monday, August 27, the captain informed the authorities that four persons on board were unconscious, one had a broken leg, and three were pregnant women. He requested that food and medical assistance be supplied. On Wednesday, August 29, the captain sent up a distress signal and then sailed into Australian territorial waters, stopping approximately four nautical miles from Christmas Island.

Responding to orders, forty-five Australian Special Armed Services troops boarded the Tampa and effectively took control of the ship. The Australian government introduced legislation into Parliament, the Border Protection Bill 2001, permitting the Tampa to be removed-as a matter of Australian law-from territorial waters. The bill was not specifically directed to the situation of the Tampa, but it would have been retrospective ${ }^{1}$ and thus applicable to that ship. It provided for discretion to effect the removal of ships from Australian territorial waters $^{2}$ and the use of reasonable force to that end. ${ }^{3}$ Court proceedings concerning such actions were not to be permitted, ${ }^{4}$ and applications for refugee status by any person on board the boat would be invalid. ${ }^{5}$ The legislation was to have effect "in spite of any other law." ${ }^{\prime 6}$ The Senate, however, defeated the bill. In any event, the captain of the Tampa had indicated that he was unable to sail from Australian waters with all the asylum seekers aboard, as the ship was seaworthy for only fifty people.

On August 30, the Norwegian ambassador to Australia was permitted to board the Tampa. He received a letter from the boat people pleading that they were refugees and effectively applying for asylum in Australia. The next day, August 31, two applications concerning the boat people were lodged in the federal court before Justice Anthony North. The applicants-the Victorian ${ }^{7}$ Council for Civil Liberties and solicitor Eric Vadarlis—sought habeas

\footnotetext{
${ }^{1}$ Border Protection Bill 2001, H.R., 39th parl., §2.

${ }^{2}$ Id., §4.

${ }^{3}$ Id.

${ }^{4}$ Id., $\$ 7$.

${ }^{5}$ Id., $\$ 9$.

${ }^{6} I d ., \$ 10$.

${ }^{7}$ Victoria is an Australian state (province).
} 
corpus and an injunction against the removal of the ship. Justice North granted a temporary injunction and set the hearing for Monday, September 3.

Meanwhile, the Australian authorities had been conducting discussions with various governments on the fate of the Tampa asylum seekers. Agreements with New Zealand and Nauru were announced on September 1, 2001. New Zealand had agreed to process 150 of the asylum seekers, particularly those in family groups, and to settle those determined to be refugees. Nauru had agreed to act as a processing center for asylum seekers, provided that Australia cover all costs and that any refugees be resettled in Australia or other countries. Arrangements were made to transfer the Tampa asylum seekers to the Australian troopship Manoora, which would take them to Papua New Guinea. From there, the asylum seekers would be flown to New Zealand and Nauru.

The parties to the actions in the federal court agreed to the lifting of the court's injunction on the basis that the government would return the asylum seekers if the applicants' case was successful. On September 11, Australian time, as the Manoora neared Papua New Guinea, Justice North held that the asylum seekers had been unlawfully detained as a matter of Australian law and ordered that they be returned to Australia. ${ }^{8}$ That night, the twin towers of the World Trade Center were destroyed by terrorists, killing thousands of innocent people.

The government successfully appealed Justice North's decision. ${ }^{9}$ In the lead judgment, the usually progressive Justice Robert French held that, although the extensive legislative powers in the Migration Act of 1958 had not been invoked, the government retained executive power to keep aliens from entering Australia ${ }^{10}$ that had not been abrogated by legislation. ${ }^{11}$ Further, as the aliens had no legal right to enter Australia, no detention had occurred and any restraint on liberty that may have been imposed was not subject to habeas corpus. ${ }^{12}$ Chief Justice Michael Black dissented. In his view, the existence of a prerogative or executive power to expel aliens was dubious, ${ }^{13}$ while the enactment of extensive legislative powers had excluded any relevant executive powers. ${ }^{14}$ Moreover, the restriction of the asylum seekers' liberty had been so significant as to amount to detention; it was attributable to the Australian federal government; and it was illegal. ${ }^{15}$

One can only speculate about the different light in which the division between legislative and executive powers may have appeared to particular judges depending on whether the court sat before or after September 11. Clearly, with a federal election looming, the attitudes of the legislature changed markedly according to the perceived impact of the events of that day on the electorate. On September 26, the Australian Parliament passed no fewer than seven bills affecting refugees, including a new version of the Border Protection Bill. Among other things, the legislation:

- "refined" the definition of refugee and the exclusion clauses (under which certain persons are barred from refugee status) $;^{16}$

— introduced a privative clause removing the possibility of judicial review in most immigration cases; ${ }^{17}$

\footnotetext{
${ }^{8}$ Victorian Council for Civil Liberties Inc. v. Minister for Immigration \& Multicultural Affairs (2001) 110 FCR 452. Most of the facts for this introduction are taken from $i d$., paras. 14-40.

${ }^{9}$ Ruddock v. Vadarlis (2001) 110 FCR 491 (Fed. Ct.) (three-judge panel).

${ }^{10} I d$., para. 193 (French, J.).

${ }^{11} I d$., para. 202.

${ }^{12} I d$., paras. 212-15.

${ }^{13} I d$., para. 29 (Black, C.J.).

${ }^{14} I d$., paras. 60-64.

${ }^{15}$ Id., paras. 80-90.

${ }^{16}$ Migration Legislation Amendment Act (No. 6) 2001 (Austl.) (inserting §§91R, S into the Migration Act 1958 (Austl.)). The Migration Act and other Australian statutes are available online at $<$ http://www.austlii.edu.au/au/ legis/cth/consol_act>.

${ }^{17}$ Migration Legislation Amendment (Judicial Review) Act 2001 (Austl.) (repealing and replacing $\$ 474$ of the Migration Act).
} 
- validated the actions related to the Tampa and introduced new interdiction powers, ${ }^{18}$

- excised certain territories from the "migration zone" (the area in which valid applications for an Australian visa may be made) for the purposes of refugee law; ${ }^{19}$

- prevented "offshore entry persons" (unauthorized entrants to the excised areas) ${ }^{20}$ from applying for protection visas in Australia, ${ }^{21}$ and permitted them to be taken offshore for the processing of their claims to refugee status; ${ }^{22}$ and

- created a new temporary visa category for offshore entry persons, ${ }^{23}$ which effectively prohibits family reunion.

The only opposition came from the smaller parties (the Democrats and Greens) ${ }^{24}$ and one independent in the Senate.

After the passage of the legislation, an application for special leave to appeal to the High Court on behalf of the asylum seekers rescued by the Tampa proved unsuccessful because the boat people were no longer detained within Australian jurisdiction and the case was therefore moot. ${ }^{25}$ In any event, the case would have been confined to a fairly limited scope in its consideration of human rights and refugee questions, revolving around the question of liberty. As significant as that question clearly is, the legislation that constitutes the legal basis for the Pacific Solution raises much larger questions concerning refugee protection.

\section{THE NEW LEgISLATIVE SCHEME}

The Pacific Solution consists of three main pieces of legislation. The first is the Border Protection (Validation and Enforcement Powers) Act of 2001 (hereinafter referred to as the "Border Protection Act" or by the sections introduced into the Migration Act). The Border Protection Act validates the actions taken in relation to the Tampa ${ }^{26}$ and enacts new border protection powers, including the power of interdiction. Section $245 \mathrm{~F}(8)$ of the Migration Act now provides that in certain cases (essentially involving suspicion of illegal immigration ${ }^{27}$ ), a ship or aircraft may be detained and brought "to a port, or to another place (including a place within the territorial sea or the contiguous zone in relation to Australia)." ${ }^{28}$ In addition, section 7A of the Migration Act now provides that " $[t]$ he existence of statutory powers under this Act does not prevent the exercise of any executive power of the Commonwealth to protect Australia's borders, including, where necessary, by ejecting persons who have crossed those borders."

\footnotetext{
${ }^{18}$ Border Protection (Validation and Enforcement Powers) Act 2001, sched. 2, cl. 7 (Austl.) (inserting $§ 245 F(8)$ into the Migration Act) \& sched. 2, cl. 2 (inserting \$7A into the Migration Act) [hereinafter Border Protection Act].

${ }^{19}$ Migration Amendment (Excision from Migration Zone) Act 2001 (Austl.) [hereinafter Excision Act].

${ }^{20}$ See the definitions in section 5 of the Migration Act, as amended by $i d$.

${ }^{21}$ Migration Act $\$ 46$ A (inserted by the Excision Act, supra note 19). Protection visas are the usual way that Australia meets its obligations under the Refugee Convention, infra note 45.

${ }^{22}$ Migration Act $\$ 198 A$ (inserted by the Migration Amendment (Excision from Migration Zone) (Consequential Provisions) Act 2001 (Austl.)).

${ }^{23}$ Visa subclass 447; see Migration Regulations 1994, cl. 447, as amended by Migration Amendment (Excision from Migration Zone) (Consequential Provisions) Act 2001. The Migration Regulations are available online at $<\mathrm{http}: / /$ www.austlii.edu.au/au/legis/cth/consol_reg/>.

${ }^{24}$ The major Australian political parties are the Liberal Party and the National Party, which generally form a coalition, and the Labor Party.

${ }^{25}$ See the transcript concerning the application for leave to appeal to the High Court in Vadarlis v. Minister for Immigration \& Multicultural Affairs, No. M93/2001 (Nov. 27, 2001, High Ct.) (three-judge panel), available at <http://www.austlii.edu.au/au/other/hca/transcripts/2001/M93/3.html>.

${ }^{26}$ Given the full federal court's decision, the government would argue that there is nothing to validate.

${ }^{27}$ The three cases enumerated in section $245 \mathrm{~F}(8)$ are (a) a craft in Australia reasonably suspected to be or to have been involved in a contravention of the Migration Act, in or outside Australia; (b) an Australian ship outside Australia where one may reasonably suspect that it is, has been, or will be involved in a contravention of the Act, either in or outside Australia; and (c) a foreign ship outside Australia where one may reasonably suspect that it is, has been, or will be involved in a contravention of the Act in Australia.

${ }^{28}$ Border Protection Act, supra note 18.
} 
The second Act is the Migration Amendment (Excision from Migration Zone) Act of 2001 (hereinafter referred to as the "Excision Act" or by the sections introduced into the Migration Act). The Excision Act removes particular territories, including Christmas, Cocos, and Ashmore and Cartier Islands, from the Australian "migration zone" to ensure that certain persons cannot make valid applications for visas. These territories are known as "offshore excised places." ${ }^{29}$ The legislation also creates a new category of unauthorized arrival-the "offshore entry person"- an unauthorized arrival who enters one of the excised offshore areas. ${ }^{30}$ Such a person is barred from applying for a protection visa, ${ }^{31}$ the grant of which is the usual way that Australia meets its obligations under the Refugee Convention. The minister for immigration may exercise noncompellable discretion to permit an offshore entry person to make a valid application, ${ }^{32}$ although precisely what kind of visa the person would be granted remains unclear.

The third Act is the Migration Amendment (Excision from Migration Zone) (Consequential Provisions) Act of 2001 (hereinafter referred to as the "Consequential Provisions Act" or by the sections introduced into the Migration Act). The Consequential Provisions Act enables Australian officials either to detain offshore entry persons in Australia ${ }^{33}$ or to take them to a "declared" country. ${ }^{34}$ The minister may declare that a particular country

(i) provides access, for persons seeking asylum, to effective procedures for assessing their need for protection; and

(ii) provides protection for persons seeking asylum, pending determination of their refugee status; and

(iii) provides protection to persons who are given refugee status, pending their voluntary repatriation to their country of origin or resettlement in another country; and

(iv) meets relevant human rights standards in providing that protection. ${ }^{35}$

Nauru and Papua New Guinea are, or are being treated as, declared countries, and Australia has negotiated "agreements" for admission of the asylum seekers with those two countries. ${ }^{36}$ So far, apart from New Zealand, other countries have not agreed to participate in the Pacific Solution, and Fiji has refused to do so. ${ }^{37}$

The Consequential Provisions Act also creates two new visa categories. Visa subclass 451 is for people intercepted on their way to Australia in transit countries like Indonesia. ${ }^{38}$ Visa subclass 447 is for "offshore entry persons." ${ }^{39}$ Both new visas are "offshore" visas, meaning that they are to be applied for from outside Australia. ${ }^{40}$ Three major preexisting offshore

\footnotetext{
${ }^{29}$ See the definitions in Migration Act $§ 5$, supra note 20.

${ }^{30} I d$.

${ }^{31}$ There are two types of onshore protection visas. Visa subclass 866 , the permanent protection visa, is available to refugees arriving in Australia on a visa (for example, a student visa), while visa subclass 785, the temporary protection visa, is now only available in principle to refugees arriving unlawfully (as a matter of Australian law) on the mainland. For the terms and conditions of these visas, see Migration Regulations, supra note 23, sched. 2, cls. 785, 866.

${ }^{32}$ Migration Act $§ 46 \mathrm{~A}(2)$.

${ }^{33} I d ., \S 189(3),(4)$.

${ }^{34} I d$., $\$ 198 \mathrm{~A}(1)$.

${ }^{35} I d ., \$ 198 \mathrm{~A}(3)(\mathrm{a})$.

${ }^{36}$ See, for example, the "Statement of Principles" signed by the president of Nauru and Australia's minister for defense on September 10, 2001 (copy on file with author). The "agreement" appears to be a memorandum of understanding, which Australia usually regards as nonbinding, and neither party seems to have registered it with the United Nations Secretary-General (not that either of these facts is determinative of the status of the agreement).

${ }^{37}$ The Australian government has presented this refusal as a withdrawal of Australia's request: "Australia welcomed the serious consideration the government of Fiji gave to its request, and in view of Fiji's current situation, decided to withdraw the request." Minister for Foreign Affairs and Trade, Media Release, Fiji Visit, FA180 (Dec. 12, 2001), at <http://www.dfat.gov.au/media/releases/foreign/2001>.

${ }^{38}$ Migration Regulations, supra note 23, sched. 2, cl. 451.

${ }^{39}$ See supra note 23.

${ }^{40}$ Migration Regulations, supra note 23, sched. 2, cls. 447.411, 451.411 (stipulating that " $[\mathrm{t}]$ he applicant must be outside Australia at the time of grant" of the visa).
} 
visa categories, the refugee, global special humanitarian, and woman-at-risk visas, were all amended so as to preclude applications by people perceived to have given up protection possibilities en route to Australia. The relevant provisions in the Migration Regulations now stipulate as a criterion for these visas that the applicant may not, since leaving the country of origin, have resided continuously for seven days in a country where effective protectioneither by the country or through the United Nations High Commissioner for Refugees (UNHCR) - could have been sought and obtained. ${ }^{41}$

The new classes of visas, unlike the three other amended offshore visa categories, are issued only for temporary periods. Visa subclass 451 is granted for five years. A permanent onshore protection visa (visa subclass 866 ) may be applied for after four and a half years. ${ }^{42}$ Visa subclass 447 is granted for three years, and holders of this visa are precluded from applying for a permanent protection visa. ${ }^{43}$ Both the 447 and 451 visas permit only one entry to Australia. Their temporary nature precludes family reunion for the duration of the visa in the case of the 451 visa category and so long as the visa holder remains in Australia in the case of the 447 visa category. ${ }^{44}$

\section{COMPATIBILITY WITH INTERNATIONAL LAW}

Australia is party to the 1951 Convention Relating to the Status of Refugees and its 1967 Protocol (hereinafter referred to together as the "Refugee Convention"). ${ }^{45}$ Australia is also party to all the major human rights instruments, including the International Covenant on Civil and Political Rights, ${ }^{46}$ the Convention Against Torture and Other Cruel, Inhuman or Degrading Treatment or Punishment ${ }^{47}$ ("Convention Against Torture"), and the Convention on the Rights of the Child. ${ }^{48}$ The legislation may result in violations of one or more of these treaties. The legislation may permit refoulement to a place of persecution or torture; it discriminates between asylum seekers; it permits detention of asylum seekers in Australia, and the agreements with declared countries contemplate detention in those countries as well; and family reunion is prevented, in some cases indefinitely. Since it is well accepted that international law prohibits detention of asylum seekers while their refugee status is being determined, unless factors relevant to the individual (for example, a high risk of absconding) require detention, ${ }^{49}$ I will not dwell on that issue here. Rather, I will focus on interdiction, the development of the idea of "protection elsewhere," and the new visa regime.

\section{Interdiction Revisited}

The Australian legislation permits the interception of asylum seekers and denial of their access to Australian procedures for determining refugee status. Once an interception has been made, the Australian authorities have two options. One is to send the asylum seekers to countries participating in the Pacific Solution. New Zealand has participated to a limited extent and has accepted asylum seekers, generally those in family groups, for refugee status determination in the normal manner. Nauru and Papua New Guinea have also participated

${ }^{41}$ Id., sched. 2, cls. 200.212, 202.212, 204.213.

${ }^{42}$ Id., sched. 2, cl. 866.228A.

${ }^{43}$ It is now a criterion for a visa subclass 866 that " $\mathrm{t}$ ] he applicant has not held a Subclass 447 (Secondary Movement Offshore Entry (Temporary)) visa since last entering Australia." Id., sched. 2, cl. 866.214(1).

${ }^{44}$ A person must be a citizen or permanent resident of Australia in order to sponsor a spouse or other family members for migration to Australia.

${ }^{45}$ Convention Relating to the Status of Refugees, July 28, 1951, 189 UNTS 150, as amended by Protocol Relating to the Status of Refugees, Jan. 31, 1967, 19 UST 6223, 606 UNTS 267 [hereinafter Refugee Convention].

${ }^{46}$ International Covenant on Civil and Political Rights, Dec. 16, 1966, 999 UNTS 171.

${ }^{47}$ Convention Against Torture and Other Cruel, Inhuman or Degrading Treatment or Punishment, opened for signature Dec. 10, 1984, 1465 UNTS 85 [hereinafter Convention Against Torture].

${ }^{48}$ Convention on the Rights of the Child, Nov. 20, 1989, 1577 UNTS 3.

${ }^{49}$ See Communication No. 560/1993, Av. Australia, UN Doc. CCPR/C/59/D/560/1993 (1997), available at <http:// www.unhchr.ch/tbs/doc.nsf>. 
in the Pacific Solution, but only as facilities for determining refugee status. The key legal issues involved in this option are whether asylum seekers may choose to enter Australia if they wish or instead can be required to access protection elsewhere, and whether their treatment in countries like Papua New Guinea is consistent with human rights standards (see the next section below).

The second, less obvious option for Australian authorities is to take boats of asylum seekers back to the high seas. This approach is permitted by the Border Protection Act, as there is no express linkage between the powers of interception contained in that $\mathrm{Act}^{50}$ and the powers to remove offshore entry persons to "declared countries" contained in the Consequential Provisions Act. ${ }^{51}$ The latter powers would not necessarily apply to persons on an interdicted ship because they would not yet meet the definition of an offshore entry person. Forcing ships back out to sea may result in refoulement, which is prohibited by the Refugee Convention and other human rights instruments. ${ }^{52}$ At the very least, the result might be "refugees in orbit"-that is, refugees traveling around, trying to secure entry to countries and being turned away. ${ }^{53}$

The Australian government appears to think that interdiction is compatible with the Refugee Convention. In support of this view, it could cite the precedent of the United States' interdiction of Haitian asylum seekers. However, although at various times the U.S. program did provide for some sort of hearings (albeit unsatisfactory ones) regarding the Haitians' claims, refugee advocates fear that many genuine refugees were rejected. ${ }^{54}$ In any event, the U.S. Supreme Court's 8-1 decision upholding the practice (Justice Harry Blackmun dissented) - which rests on the supposed territorial scope of the Refugee Convention ${ }^{55}$ - has been criticized. $^{56}$

The assumption underlying the Supreme Court's decision and Australia's adoption of the practice of interdiction-that extraterritorial interception (or, in the case of the Tampa, interception within the territorial sea) of asylum seekers is permissible-is generally not accepted. Article 33 of the Refugee Convention expressly refers to refoulement "in any manner whatsoever." Chain refoulement by causing a person to return to another place from which refoulement occurs is prohibited. ${ }^{57}$ Rejection of asylum seekers at the frontier is also prohibited by this phrase and agreement as to the interpretation of the Convention on this point is reflected in numerous conclusions of the Executive Committee of the UNHCR. ${ }^{58}$

\footnotetext{
${ }^{50}$ See the text at and following supra note 26.

${ }^{51}$ See supra note 22.

${ }^{52}$ Refoulement is prohibited by Article 33 of the Refugee Convention, supra note 45; Article 3 of the Convention Against Torture, supra note 47; implicitly, Articles 6 and 7 of the International Covenant on Civil and Political Rights, supra note 46; and Article 22 of the Convention on the Rights of the Child, supra note 48.

${ }^{53}$ See generally GÖRAN MELANDER, REFUGEES IN ORBIT (International University Exchange Fund, 1978).

${ }^{54}$ Harold Hongju Koh, America's Offshore Refugee Camps, 29 U. RICH. L. REV. 139, 139-58 (1994); Carlos Ortiz Miranda, Haiti and the United States During the 1980s and 1990s: Refugees, Immigration, and Foreign Policy, 32 SAN DiEGo L. REV. 673, 693-94 (1995).

${ }^{55}$ Sale v. Haitian Centers Council, Inc., 113 S.Ct. 2549, 2563-66 (1993). The Court's decision is premised largely on the presumption against extraterritorial application of the relevant U.S. statute, 8 U.S.C. $\$ 1253(\mathrm{~h})(1)(2000)$, but the Convention itself was also considered.

${ }^{56}$ See, e.g., GuY S. Goodwin-Gill, The Refugee in International Law 143 (2d ed. 1996); Arthur C. Helton, The United States Government Program of Intercepting and Forcibly Returning Haitian Boat People to Haiti: Policy Implications and Prospects, 10 N.Y.L. SCH. J. HUM. RTS. 325, 339-42 (1993).

${ }^{57}$ See James Crawford \& Patricia Hyndman, Three Heresies in the Application of the Refugee Convention, 1 INT'LJ. REFUGEE L. 155, 171 (1989).

${ }^{58}$ UNHCR Executive Committee, Conclusion No. 85 (XLIX), International Protection, para. (q) (1998) [hereinafter Conclusion No. 85]; Conclusion No. 82 (XLVIII), Safeguarding Asylum, para. (d) (iii) (1997); Conclusion No. 22 (XXXII), Protection of Asylum-Seekers in Situations of Large-Scale Influx, para. 2 (1981); Conclusion No. 6 (XXVIII), Non-Refoulement, para. (c) (1977). The Executive Committee's conclusions are available online at <http://www.unhcr.ch/cgi-bin/texis/vtx/home/>. These conclusions are part of the soft law used to interpret the Refugee Convention. Jerzy Sztucki, The Conclusions on the International Protection of Refugees Adopted by the Executive Committee of the UNHCR Programme, 1 INT'L J. REFUGEE L. 285 (1989). This is because they are an indication of consensus on particular questions of refugee protection. Volker Türk, The Role of UNHCR in the Development of International Refugee Law, in REFUGEE RIGHTS AND REALITIES: EVOLVING INTERNATIONAL CONCEPTS AND REGIMES 153, 165 (Frances Nicholson \& Patrick Twomey eds., 1999).
} 
Article 3(1) of the General Assembly's Declaration on Territorial Asylum ${ }^{59}$ also recognizes the principle of nonrejection at the frontier. ${ }^{60}$ Just as other human rights obligations cannot be avoided by extraterritorial exercises of jurisdiction, ${ }^{61}$ so the obligation not to reject refugees and asylum seekers at the frontier cannot be avoided by the exercise of extraterritorial jurisdiction by a state that luxuriates in the absence of land borders. ${ }^{62}$

Ultimately, the legality of the interdiction program depends on the risks of refoulement. No asylum seeker has been returned directly to a place of persecution. On the other hand, Australia has not put in place satisfactory safeguards against chain refoulement. Several vessels have now been escorted back to Indonesian waters, ${ }^{63}$ and the Australian government clearly wants boats to return to Indonesia in the future. Indonesia is not a party to the Refugee Convention. In actuality, Indonesia grants temporary refuge, a practice that may support the customary international legal status of non-refoulement. ${ }^{64}$ However, refuge is granted on the basis that Western countries of immigration such as Canada, the United States, and Australia will take responsibility for resettling the refugees. ${ }^{65}$ It is thus questionable whether refuge in Indonesia constitutes protection elsewhere.

\section{Extending the Concept of "Protection Elsewhere"}

"Protection elsewhere" is relied on under the new Australian arrangements in two ways. First, Australia seeks to deny access to its procedures for determining refugee status on the basis that asylum seekers had or could have had access to protection in a country they had transited. Second, asylum seekers are taken to countries participating in the Pacific Solution, which were not transited by the asylum seekers and which, under the legislation, must be declared by the minister to meet certain minimum safeguards. In both cases, the Australian legislation copies, extends, or varies the idea of "protection elsewhere" developed in Europe and the United States and accepted, to some degree, by the UNHCR Executive Committee.

The concept of "protection elsewhere" raises two issues. The first is whether asylum seekers may have the right to choose a country of asylum-a question upon which the Refugee Convention is largely silent. The second is whether refugees are "protected" in the place where they are sent. Protection encompasses prevention of refoulement, but it also extends to safeguarding basic human rights. This interpretation has been accepted in key resolutions of the UNHCR Executive Committee discussed below, by some jurists, ${ }^{66}$ and in some state practice. ${ }^{67}$

The two questions of protection and "choice" as to a particular country of asylum are often closely linked. Many asylum seekers are forced to move on because they do not receive adequate protection at their first port of call. Such asylum seekers often arrive in Australia

\footnotetext{
${ }^{59}$ GA Res. 2312 (XXII), UN GAOR, 22d Sess., Supp. No. 16, at 81, UN Doc. A/6716 (1967), available at <http:// www.unhchr.ch/html/menu3/b/o_asylum.htm>.

${ }^{60}$ Assembly resolutions are evidence of states' views of the law. Military and Paramilitary Activities in and Against Nicaragua (Nicar. v. U.S.), Merits, 1986 ICJ REP. 14, para. 188 (June 27).

${ }^{61}$ See, for example, the decisions of the Human Rights Committee concerning interpretation of the words "territory and jurisdiction" in the cases against Uruguay involving the issue of passports and kidnapping by Uruguayan authorities in neighboring countries, discussed in MANFRED NOWAK, U.N. COVENANT ON CIVILAND POLITICAL RIGHTS: CCPR COMMENTARY 41-43 (1993).

${ }^{62}$ See, for example, the conclusion reached by Elihu Lauterpacht and Daniel Bethlehem, The Scope and Content of the Principle of Non-Refoulement, para. 67, opinion prepared for the UNHCR global consultations (June 20, 2001), at <http://www.unhcr.ch/cgi-bin/texis/vtx/home?page=events $>$.

${ }^{63}$ Philip Ruddock, Minister for Immigration and Multicultural and Indigenous Affairs, Media Release, Suspected Illegals Turned Back, MPS 193/01 (Dec. 21, 2001), at<http://www.minister.immi.gov.au/media_releases).

${ }^{64}$ For discussion of the customary law status of non-refoulement, see GoODWIN-GILL, supra note 56, at 134-37.

${ }^{65}$ See, e.g., International Conference on Indo-Chinese Refugees, Declaration and Comprehensive Plan of Action, June 13-14, 1989, UN Doc. A/CONF.148/2, pt. E, excerpted in id. at 534.

${ }^{66}$ E.g., Jens Vedsted-Hansen, Non-Admission Policies and the Right to Protection: Refugees' Choice Versus States' Exclusion? in REFUGEE RIGHTS AND REALITIES, supra note 58, at 269, 283.

${ }^{67}$ Australia's own practice recognizes the relevance of general human rights in the declarations as to a particular country's safety under both sections $91 \mathrm{~N}$ and 198A of the Migration Act.
} 
because so many countries in the Asian region are not party to the Refugee Convention. What constitutes protection in countries participating in the Pacific Solution is also an issue since Nauru is not party to the Refugee Convention or, indeed, any major human rights instruments other than the Convention on the Rights of the Child, while Papua New Guinea is party to the Refugee Convention and Protocol but maintains significant reservations concerning fundamental rights such as the rights to work, public education, and freedom of movement. $^{68}$

A right to choose a country of asylum? The concept of "protection elsewhere" is controversial, as some states argue against giving asylum seekers any choice as to the country of asylum, while refugee advocates sometimes argue in favor of giving them an unfettered choice. An accurate reading of the law may lie somewhere between these extremes. ${ }^{69}$

On the one hand, the Refugee Convention does not contain a right to enter any particular country and its provisions are designed only for those who have nowhere else to go ${ }^{70}$ Moreover, Article 31 of the Convention, which prohibits the imposition of penalties on refugees for unlawful arrival, speaks of their "coming directly" from places of persecution. Restrictions on the freedom of movement of such refugees may be imposed if necessary and "until their status in the country is regularized or they obtain admission into another country." ${ }^{71}$ States parties are to "allow such refugees a reasonable period and all the necessary facilities to obtain admission into another country."72

On the other hand, the primary purpose of Article 31 is to prevent the imposition of penalties rather than to permit states to send refugees elsewhere ${ }^{73}$ During the drafting, a proposal to amend Article 31 so that it would provide immunity from penalties only to refugees who could prove they were unable to find even temporary asylum in another country was dropped. ${ }^{74}$ As noted by Goodwin-Gill:

The intention, reflected in the practice of some States, appears to be that other countries or territories passed through should also have constituted actual or potential threats to life or freedom, or that onward flight may have been dictated by the refusal of other countries to grant protection or asylum, or by the operation of exclusionary provisions, such as those on safe third country, safe country of origin or time limits. The criterion of "good cause" for illegal entry is clearly flexible enough to allow the elements of individual cases to be taken into account. ${ }^{75}$

Indeed, many would support the view that asylum seekers have some choice concerning the country of asylum. In the Adimi case, Simon Brown, L.J., stated that

some element of choice is indeed open to refugees as to where they may properly claim asylum. I conclude that any merely short-term stopover en route to [an] intended sanctuary cannot forfeit the protection of [Article 31], and that the main touchstones by which exclusion from protection should be judged are the length of stay in the intermediate

\footnotetext{
${ }^{68}$ Papua New Guinea has lodged reservations to Articles 17(1), 21, 22(1), 26, 31, 32, and 34 of the Refugee Convention, supra note 45 .

${ }^{69}$ For a detailed explanation as to the difficulty of drawing a definitive conclusion from the Refugee Convention itself, see Vedsted-Hansen, supra note 66.

${ }^{70}$ Professor Hathaway conceptualizes the Refugee Convention as offering surrogate protection to refugees only when national protection is not forthcoming. JAMES C. HATHAWAY, THE LAW OF REFUGEE STATUS 189 (1991). Support for this idea may be drawn from Article 1A(2), second para., Article 1E, and Article 1C(5) and (6) of the Refugee Convention, supra note 45.

${ }^{71}$ Refugee Convention, supra note 45, Art. 31 (emphasis supplied).

${ }^{72} I d$.

${ }^{73}$ Rosemary Byrne \& Andrew Shacknove, The Safe Country Notion in European Asylum Law, 9 HARV. HUM. RTS.J. 185,190 (1996).

${ }^{74}$ See Nazaré Albuquerque Abell, The Compatibility of Readmission Agreements with the 1951 Convention Relating to the Status of Refugees, 11 INT'L J. REFUGEE L. 60, 78 (1999); Guy S. Goodwin-Gill, Article 31 of the 1951 Convention Relating to the Status of Refugees: Non-penalization, Detention and Protection, para. 24, paper prepared for the UNHCR global consultations (Oct. 2001), at <http://www.unhcr.ch/cgi-bin/texis/vtx/home?page=events .

${ }^{75}$ Goodwin-Gill, supra note 74, para. 28.
} 
country, the reasons for delaying there (even a substantial delay in an unsafe third country would be reasonable were the time spent trying to acquire the means of travelling on), and whether or not the refugee[s] sought or found there protection de jure or de facto from the persecution they were fleeing. ${ }^{76}$

An early conclusion of the UNHCR Executive Committee gives some support to the idea of a limited choice for asylum seekers and recognizes that they may have valid reasons for wishing to go to a particular country of asylum, such as the presence of family members. The committee's Conclusion No. 15 sets out criteria for identifying the state responsible for examining an asylum request. ${ }^{77}$ The criteria to be taken into account include "the duration and nature of any sojourn of the asylum-seeker in other countries"; ${ }^{78}$ the "intentions of the asylum-seeker as regards the country in which he wishes to request asylum"; $;{ }^{79}$ the fact that "asylum should not be refused solely on the ground that it could be sought from another State"; and a "connection or close links with another State" that, if it appears "fair and reasonable," may justify calling upon the asylum seeker to request asylum from that state in the first instance. ${ }^{81}$

State practice is not fully congruent with Conclusion No. 15. The leading example is the Convention Determining the State Responsible for Examining Applications for Asylum Lodged in One of the Member States of the European Communities ("Dublin Convention") ${ }^{82}$ The Dublin Convention permits return to members of the European Union (EU) - all of which are party to the Refugee Convention and bound by the non-refoulement obligation in the European Convention for the Protection of Human Rights and Fundamental Freedomswhere entry to the Union has occurred through that state. ${ }^{83}$ The Convention, however, does acknowledge the importance of links between the asylum seeker and the country of refuge in cases involving family life or humanitarian considerations. ${ }^{84}$ The Dublin Convention also permits return to non-EU member states ${ }^{85}$ which are sometimes not party to the Refugee Convention. European states have often adopted lists of "safe third countries" to which asylum seekers may be returned ${ }^{86}$ - a practice also adopted by Australia in the Border Protection Legislation Amendment Act $1999^{87}$ and by other states. ${ }^{88}$

Implementing the Dublin Convention has been difficult, because of the need to prove that illegal entrants transited another country, among other things. ${ }^{89}$ In practice, the spontaneous arrival of asylum seekers still determines where asylum applications are lodged, meaning

\footnotetext{
${ }^{76}$ Regina v. Uxbridge Magistrates Court, ex parte Adimi, [1999] 4 All E.R. 520, 527-28 (Q.B.) (Simon Brown, L.J.); see also id. at 537 (Newman, J.).

${ }^{77}$ UNHCR Executive Committee, Conclusion No. 15 (XXX), Refugees Without an Asylum Country (1979).

${ }^{78} I d$., para. (h) (ii).

${ }^{79} I d$., para. (h) (iii).

${ }^{80} I d$., para. (h) (iv).

${ }^{81} I d$.

${ }^{82}$ Convention Determining the State Responsible for Examining Applications for Asylum Lodged in One of the Member States of the European Communities, June 15, 1990, 30 ILM 425 (1991) [hereinafter Dublin Convention].

${ }^{83} I d$., Arts. 5, 6, 7. For the European Convention for the Protection of Human Rights and Fundamental Freedoms, Nov. 4, 1950, see 213 UNTS 221. Article 3 implicitly prohibits torture. See, e.g., Soering v. United Kingdom, 161 Eur. Ct. H.R. (ser. A) (1989).

${ }^{84}$ Dublin Convention, supra note 82, Art. 9. In addition, Article 3(4) recognizes the ability of states parties to take responsibility outside the usual Dublin Convention principles.

${ }^{85}$ Id., Art. 3(5).

${ }^{86}$ Sabine Weidlich, First Instance Asylum Proceedings in Europe: Do Bona Fide Refugees Find Protection? 14 GEO. IMMIGR. L.J. 643, 652 (2000).

${ }^{87}$ Migration Act $§ 91 \mathrm{~N}$.

${ }^{88}$ Joanne van Selm, Access to Procedures: "Safe Third Countries," "Safe Countries of Origin," and "Time Limits," para. 47, background paper for the third track of the UNHCR global consultations (June 2001), at $<$ http://www.unhcr.ch/cgibin/texis/vtx/home?page=events $>$.

${ }^{89}$ European Council on Refugees and Exiles, Comments on the Proposal for a Council Regulation Establishing the Criteria and Mechanisms for Determining the Member State Responsible for Examining an Asylum Application Lodged in One of the Member States by a Third Country National 1-3 (Dec. 2001), available at <http:// www.ecre.org/eu_developments/stateresp.shtml>.
} 
effectively that the asylum seeker has "chosen" the country of refuge. Since it may be equally, if not more, unfair to both states and asylum seekers to let responsibility rest on the country an asylum seeker first entered, just as it is unfair for countries with a strong economy to be the ultimate destination of asylum seekers, it may well be that states should accept the idea that asylum seekers have some choice. The European Council on Refugees and Exiles has urged the European Union to move away from the premises of the Dublin Convention and to accept that responsibility for determining refugee status rests with either the state in which an asylum seeker's family is present or the state in which an asylum application is lodged..$^{90}$

Notably, even the Kosovo evacuation program to third countries, including Australia-a situation of mass influx where a solidarity mechanism is required-was consensual, ${ }^{91}$ in contrast to Australia's removal of asylum seekers to countries participating in the Pacific Solution. The new EU directive on temporary protection also requires asylum seekers to consent before being transferred to another state. ${ }^{92}$ Australia's policy, however, is more like the U.S. policy of removing Haitian and Cuban asylum seekers involuntarily to "offshore safe haven camps."

The number of asylum seekers arriving spontaneously in Australia is so small ${ }^{94}$ and the country so well placed to accept them because of its relative economic strength, its multicultural society, and the presence of many of the asylum seekers' families that talk about "burden sharing" on Australia's part is disingenuous. The government's rhetoric ${ }^{95}$ demonstrates the point made by Deborah Anker, Joan Fitzpatrick, and Andrew Shacknove ${ }^{96}$ that talk of burden sharing may be used by "sophisticated Northern governments" to abrogate their international obligations while neglecting to provide financial assistance to other states. ${ }^{97}$ The Pacific Solution involves the payment of money to Pacific islands only for the short-term object of processing asylum seekers, and it has preyed on and distorted an already unequal relationship between Australia and Pacific states. ${ }^{98}$

What constitutes "protection"? Regardless of whether asylum seekers have the right to choose a country of asylum, it is essential that any putative safe third country provide protection. The Australian legislation and practice is deficient on this score. This comes as no surprise in view of the government's apparent focus on deterrence and the allocation of blame for not having accessed protection in the past, rather than on whether protection is now achievable in a third country.

Three conclusions of the UNHCR Executive Committee deal with protection elsewhere. Conclusion No. 15, which considers the selection of the state responsible for determining a claim to refugee status, has already been mentioned.$^{99}$ The situation of asylum seekers who

\footnotetext{
${ }^{90} I d$. at 3.

${ }^{91}$ UNHCR Skopje, Guidelines for the Humanitarian Evacuation Programme of Kosovar Refugees in the Former Yugoslav Republic of Macedonia (Apr. 11, 1999), at <http://www.refugees.net/en/evacuations.html $>$. Australia's regulations speak of asylum seekers' acceptance of offers of temporary stay in Australia. Migration Regulations, supra note 23, reg. 2.07AC.

${ }^{92}$ Council Directive 2001/55/EC of 20 July 2001 on Minimum Standards for Giving Temporary Protection in the Event of a Mass Influx of Displaced Persons and on Measures Promoting a Balance of Efforts Between Member States in Receiving Such Persons and Bearing the Consequences Thereof, 2001 O.J. (L 212) 12, Art. 26(1).

${ }^{93}$ For discussion of this policy, see T. Alexander Aleinikoff, Safe Haven: Pragmatics and Prospects, 35 VA. J. INT'L L. 71 (1994); Koh, supra note 54.

${ }^{94}$ In the period between July 1, 2000, and June 31, 2001, there were 1508 unlawful air arrivals and 4141 unlawful arrivals by boat in Australia. Department of Immigration and Multicultural and Indigenous Affairs, Fact Sheet 70 , Border Control (Nov. 19, 2001), available at <http://www.immi.gov.au/facts/70border.htm>. In 2000 the total number of asylum applications in Australia was 19,400. UNHCR, Refugees by Numbers 2001, at 8, available at <http:// www.unhcr.ch/cgi-bin/texis/vtx/home?page=basics $>$.

${ }^{95}$ See particularly Philip Ruddock, Australian Statement to Parties to the Convention Related to the Status of Refugees, UNHCR Ministerial Council (Dec. 12, 2001), at <http://www.minister.immi.gov.au/transcripts/index.htm>.

${ }_{96}$ Deborah Anker, Joan Fitzpatrick, \& Andrew Shacknove, Crisis and Cure: A Reply to Hathaway/Neve and Schuck, 11 HARV. HUM. RTS. J. 295 (1998).

${ }^{97}$ Id. at 304 .

${ }^{98}$ Greg Fry, The 'Pacific Solution'? in REFUGEES AND THE MYTH OF THE BORDERLESS WORLd 23, 26 (Australian National University, Dep't of Int'l Relations, 2002).

${ }^{99}$ See supra note 77.
} 
have already been granted "protection" is dealt with in Conclusion No. $58 .{ }^{100}$ That conclusion states that the "irregular" movement of persons who have been protected from refoulement (but who have not necessarily been accorded a durable solution such as local integration) is undesirable. It provides that return of such asylum seekers to a safe third country is permissible if the refugees or asylum seekers will continue to be protected from refoulement and "permitted to remain there and ... be treated in accordance with recognized basic human standards until a durable solution is found for them."101 "Favourable consideration" is to be given to cases where a refugee or asylum seeker "may justifiably claim that he has reason to fear persecution or that his physical safety or freedom are endangered in a country where he previously found protection." ${ }^{102}$ Finally, Conclusion No. $85^{103}$ requires that any country to which asylum seekers are sent should observe their human rights, protect them from refoulement, and provide an opportunity for them to seek and enjoy asylum.

In addition to observing the requirements of the committee's conclusions, the state of arrival should conclude an admission agreement with the putative safe country. In the absence of such an agreement, only the state of nationality has an obligation to admit a person to its territory. Decisions to send particular asylum seekers to a putative safe third country should also be communicated to that country to avoid misunderstandings about the reason for the asylum seekers' arrival. ${ }^{104}$ Such misunderstandings can lead to refoulement.

Australia's practice of returning people to Indonesia does not meet these requirements. Protection from refoulement is uncertain. Once asylum seekers have left Indonesia, they probably do not have a legal right to reenter the country under Indonesian national law. Although it is strongly arguable that customary international law obliges Indonesia not to expel the asylum seekers, it is unsafe to rely on this obligation in the absence of an admission agreement, just as it would be unsafe to send an asylum seeker off to another country simply because it is party to the Refugee Convention. Australia relies on Indonesia's participation in an arrangement with Australia whereby Indonesia intercepts asylum seekers on the way to Australia; ${ }^{105}$ however, the two countries appear not to have made an express agreement concerning the readmission of asylum seekers once they have left.

Whether temporary refuge in Indonesia qualifies as "protection" in a broader sense is also questionable. It is not the equivalent of refugee status with all its attendant rights, and one may doubt whether Indonesia can protect and ensure the fundamental human rights of asylum seekers, even given the assistance of the Australian government and the International Organisation for Migration. Australia relies on UNHCR's presence in Indonesia as a guarantee of protection. ${ }^{106}$ However, the mandate of UNHCR is limited. It can recognize refugees and provide humanitarian assistance-despite severe budgetary constraints-but it does not have the territorial base of a state. Thus, although its Statute speaks of securing "international protection," ${ }^{107}$ UNHCR must work with states to achieve this goal. ${ }^{108}$ In practice, UNHCR's

\footnotetext{
${ }^{100}$ UNHCR Executive Committee, Conclusion No. 58 (XL), Problem of Refugees and Asylum-Seekers Who Move in an Irregular Manner from a Country in Which They Had Already Found Protection (1989).

${ }^{101} I d$., para.(f) (ii).

${ }^{102} I d$., para. (g).

${ }^{103}$ See supra note 58.

${ }^{104}$ See Reinhard Marx, Non-Refoulement, Access to Procedures, and Responsibility for Determining Refugee Claims, 7 INT'L J. REFUGEE L. 383, 404 (1995), and his numbered conclusions 3 and 4 at 405.

${ }^{105}$ Principled Observance of Protection Obligations and Purposeful Action to Fight People Smuggling and Organised Crime-Australia's Commitment 5-7 (2001) [hereinafter Principled Observance] (on file with author). For further information about the arrangement, see U.S. Committee for Refugees, Paying the Price: Australia, Indonesia Join Forces to Stop "Irregular Migration" of Asylum Seekers, REFUGEE REP., Aug./Sept. 2001, at <http://www.refugees.org/ world/themes/asylum.htm>.

${ }^{106}$ Principled Observance, supra note 105; see also supra note 41 and corresponding text (noting that amendments to the major offshore visa categories speak of "effective protection" by either the state or UNHCR).

${ }^{107}$ Statute of the Office of the United Nations High Commissioner for Refugees, GA Res. 428(V), annex, paras. 1,8 (Dec. 14, 1950), excerpted in GoODWIN-GILL, supra note 56, at 384.

${ }^{108}$ This limitation is particularly apparent from the language used in paragraph 8 of the Statute, id.
} 
powers concerning countries' obligations of protection are limited to suasion, ${ }^{109}$ and the agency certainly cannot compel a country to accept refugees as permanent residents. For Australia to push its "refugee problem" back on developing countries and a cash-strapped international organization unconscionably inverts its responsibilities.

Australia also relies on "declared countries" to provide protection during the determination of asylum seekers' status, which extends the notion of "safe third countries" adopted in Australia, Europe, and elsewhere ${ }^{110}$ to countries that have simply agreed to determine refugee status as opposed to providing full refugee protection. The reliance on declared countries shares at least one problem with the more usual practice of listing particular countries as safe-namely, failure to consider the position of the individual asylum seeker and the possibility of refoulement that flows from this failure. The ministerial declaration contemplated in section 198A of the Migration Act refers to the general situation in the declared country, rather than the position of individual asylum seekers. Section 46A(2) of the Migration Act makes provision for ministerial discretion to lift the bar on valid visa applications in Australia if it would be in the public interest. However, the Act does not suggest any factors that the minister might take into account. ${ }^{111}$ Presumably, it would serve the public interest for the minister to take into account considerations relating to individuals for the purposes of section $46 \mathrm{~A}(2)$, given that Australia would be in violation of international law if these factors were not considered. However, ministerial discretion is not the same as mandatory consideration of these issues and may therefore not suffice to meet Australia's international obligations.

It is also unclear how "an opportunity to seek and enjoy asylum" 112 is offered by countries that merely act as processing centers. However, since Australia is supposed to remove all asylum seekers, including those determined to be refugees, from the "declared countries," it may be accepted that an opportunity to seek and enjoy asylum is granted indirectly. If no third country agrees to protect the refugees, it is suggested that Australia would be obliged to provide protection itself. ${ }^{113}$ Certainly, detention of asylum seekers in declared countries does not conform to "accepted international standards." ${ }^{114}$ In Nauru, for example, asylum seekers are held in conditions that amount to detention for the duration of their stay, ${ }^{115}$ which is a violation of human rights ${ }^{116}$ and an example of refugee "warehousing"117 - treatment for which Australia should be viewed as jointly responsible at international law. ${ }^{118}$

\section{The New Visa Regime}

The new visas are best understood as an extension of the Australian government's longterm view that many onshore asylum seekers in Australia are "forum-shoppers." In 1999 temporary, as opposed to permanent, protection visas were introduced for onshore applicants for refugee status who had arrived without a visa. ${ }^{119}$ Also in 1999 the Migration Act was amended

\footnotetext{
${ }^{109}$ Of course, states parties to the Refugee Convention owe a specific duty of cooperation to UNHCR under Article 35 of the Convention. For nonparties, UNHCR's status as a subsidiary organ of the General Assembly gives it some status.

${ }^{110}$ See supra note 86 and corresponding text.

${ }^{111}$ This omission may be contrasted with the amendments introduced by the Border Protection Legislation Amendment Act 1999. See Migration Act $\$ 91$ (Q) (1), (2).

${ }^{112}$ Conclusion No. 85, supra note 58; see supra text at note 103.

${ }^{113}$ It seems highly likely that Nauru would regard the "Statement of Principles," supra note 36, as legally binding and, moreover, that Australia might be estopped from failing to remove the asylum seekers.

${ }^{114}$ Conclusion No. 85, supra note 58.

${ }^{115}$ John P. Pace, Report of Mission to the Republic of Nauru, paras. 51-56 (Amnesty International, Nov. 16, 2001) (on file with author).

${ }^{116}$ See A v. Australia, note 49 supra.

${ }^{117}$ James C. Hathaway \& R. Alexander Neve, Making International Refugee Law Relevant Again: A Proposal for Collectivized and Solution-Oriented Protection, 10 HARV. HUM. RTS. J. 115, 130-31 (1997).

${ }^{118}$ See Draft Articles on State Responsibility for Internationally Wrongful Acts, Report of the International Law Commission on the Work of Its Fifty-third Session, UN GAOR, 56th Sess., Supp. No. 10, ch. IV.E.1, UN Doc. A/56/10 (2001).

${ }^{119}$ See supra note 31 concerning permanent and temporary protection visas.
} 
by the Border Protection Legislation Amendment Act to ensure that persons with a right to enter and reside in another country could be sent there instead of being granted refugee status in Australia. ${ }^{120}$ These amendments were entitled "amendments to prevent forum-shopping." The second-reading speech for the Consequential Provisions Act also adopts the rhetoric that forum shopping should be prevented. ${ }^{121}$

The enactment of the Consequential Provisions Act on top of the introduction in 1999 of temporary visas for unlawful arrivals has created a many-layered hierarchy of refugees in Australia that has little bearing on protection needs. Successful onshore claimants for protection who arrive in Australia on a visa, and successful offshore claimants who are not perceived to have given up prior protection opportunities, are given permanent protection. ${ }^{122}$ Successful onshore claimants who arrive on the mainland unlawfully are given three-year temporary protection visas in the first instance,${ }^{123}$ though they may eventually apply for a permanent protection visa. Asylum seekers will now find it rather difficult to access this kind of visa, since many of them will arrive in the excised offshore areas. Successful offshore claimants intercepted while attempting to journey to Australia are given a five-year temporary entry permit in the first instance. ${ }^{124}$ Successful "offshore entry persons"-those onshore claimants who arrive in one of the excised territories of Christmas, Cocos, or Ashmore and Cartier Islands, rather than the mainland-are granted rolling three-year temporary visas after effectively (barring the exercise of the minister's discretion) being treated as offshore claimants. The last three kinds of visa do not carry reentry rights and so long as the person's status is temporarywhich is indefinitely in the case of offshore entry persons-family reunion is prevented. ${ }^{125}$

As argued previously, attempts to preclude any choice as to the place of asylum are misguided for both principled and pragmatic reasons. The new visa regime grants Australian "protection" to a degree, but it also serves to punish people who are perceived as having given up protection options elsewhere, without much consideration as to whether those options were adequate or are currently available. Thus, it may be challenged on the basis that it constitutes invidious discrimination and, effectively, a form of punishment for illegal entry into Australia. The new visa regime may also violate or put at risk other substantive rights, among them protection against refoulement and the right to family unity.

Punishment and invidious discrimination. Article 31 of the Refugee Convention forbids the application of penalties to refugees who have entered a state unlawfully. Three questions arise in relation to the conformity of the new visas for offshore entry persons with Article 31. First, one has to consider the impact of the treatment of offshore entry persons as offshore applicants for refugee status. Such persons would normally fall outside the scope of a state's obligations under the Refugee Convention. Arguably, the effort to avoid the application of Article 31 of the Convention through the treatment of offshore entry persons as offshore claimants is a bad faith interpretation of Australia's legal obligations, ${ }^{126}$ since, as argued previously, it is difficult to see how Australia can avoid ultimate responsibility for the refugees under the Refugee Convention. ${ }^{127}$

\footnotetext{
${ }^{120}$ Migration Act $\S 36(3)-(6), 91 N$.

121 "The refugees convention does not confer a right on any of these people to choose their country of asylum. ... [T] he bill amends the migration regulations to implement a visa regime aimed at deterring further movement from, or the bypassing of, other safe countries." Philip Ruddock, 39 CTH. PARL. DEB., H.R. (Hansard) (Sept. 18, 2001) $30,871,30,872$.

${ }^{122}$ The three major offshore visas for refugees-the refugee visa subclass 200, the global special humanitarian visa subclass 202, and the woman-at-risk visa subclass 204-are all permanent visas. Migration Regulations, supra note 23, sched. 2, cls. 200.511, 202.511, 204.511.

${ }^{123}$ Id., cl. 785.

${ }^{124} I d .$, cl. 451.

125 See supra note 44.

${ }^{126}$ As stated in Articles 26 and 31 of the Vienna Convention on the Law of Treaties, opened for signature May 23, 1969, 1155 UNTS 331 (a codification of customary international law), treaties are to be interpreted and implemented in good faith by the parties.

${ }^{127}$ See text supra at notes 112-13.
} 
The second question relates to the meaning of the term "penalty." Clearly, this word encompasses the imposition of criminal sanctions for unlawful entry. However, it may also prohibit all forms of discrimination between lawful and unlawful arrivals. As stated in a decision by the English Social Security Commissioner, any other construction "puts form above substance."128

The third question is whether the imposition of a lower form of protection for "asylum-shoppers" is permissible. Article 31 speaks of refugees who come "directly from a territory where their life or freedom was threatened," suggesting that it may be permissible to discriminate according to the route taken to reach Australia. However, the Australian legislation does not permit even those "offshore entry persons" who have come directly from their country of origin to access the usual procedures for determining refugee status unless the minister lifts the bar on valid applications. Nor are refugees given the opportunity to explain why they were unable to seek protection in the countries they transited, unless the minister takes such an explanation into account in the exercise of his discretion to permit a visa application by an offshore entry person ${ }^{129}$ - though Article 31 is clearly intended to allow unlawful entrants that opportunity. ${ }^{130}$

Even if Article 31 of the Refugee Convention is strictly interpreted to refer only to criminal punishments, rather than discrimination, or to penalties for unlawful entry rather than "asylum-shopping" in conjunction with illegal entry, other prohibitions on discrimination may come into play. Article 26 of the International Covenant on Civil and Political Rights, for example, applies where national laws adopt a distinction that is neither reasonable nor objective. ${ }^{131}$ Generally, aliens do not have a right to enter a particular country. However, refugees may prove an exception in practice because of the need to give effect to the obligation of nonrefoulement and other human rights obligations. ${ }^{132}$ Thus, if protection is given to refugees, but its level or type varies on a basis that is not objective and reasonable, Article 26 may arguably have been violated. All refugees require protection, above all, but not exclusively, protection from refoulement. Any discrimination between refugees on the basis of their mode of arrival (for example, its unlawfulness) may be considered invidious discrimination, as may discrimination according to route, if the refugees' valid reasons for taking that route are not taken into account. Furthermore, while the new Australian legislation may be intended to target refugees who have transited other countries en route to Australia and could have accessed protection there, visa subclass 447 for offshore entry persons is actually premised on the point of arrival in Australia. This is a nonsensical basis for providing different levels of protection.

Non-refoulement and reentry rights. Failure to guarantee the reentry of refugees to Australia risks refoulement. Whether asylum seekers could have accessed protection in a country like Indonesia at one time is beside the point. What matters now is that these refugees may not be able to reenter Indonesia or any other country than the persecutory country of origin. Convention refugees must be permitted to reenter under Article 28 of the Convention and paragraph 13 of the schedule to the Convention. Moreover, refugees-like all human beings-have the right to leave any country, ${ }^{133}$ and this right is rendered ineffective for refugees at risk of refoulement if they have no corresponding right of reentry.

The right to family unity. A third major human rights obligation thwarted by the new visa regime is the duty to respect family unity. Though not enumerated as a hard legal obligation

\footnotetext{
${ }^{128}$ Decision of the Social Security Commissioner, Case No. CIS 4439/98, para. 16 (Nov. 25, 1999), at <http:// www.courtservice.gov.uk/tribunals/tribs_home.htm>.

${ }^{129}$ The return of a Chinese woman to face a compulsory abortion in the eighth month of her pregnancy demonstrates that noncompellable discretion does not always fulfill Australia's human rights obligations. See SENATE LEGAL AND CONSTITUTIONAL COMMITTEE [Austl.], A SANCTUARY UNDER REVIEW: AN EXAMINATION OF AUSTRALIA'S REFUGEE AND HUMANITARIAN DETERMINATION PROCESSES, ch. 9 (2000).

${ }^{130}$ See text supra at note 75 .

${ }^{131}$ See the case law discussed in NOWAK, supra note 61, at 467-75.

${ }^{132}$ As Goodwin-Gill notes, "'No duty to admit' begs many questions ... . State practice in fact attributes little weight to the precise issue of admission, but far more to the necessity for non-refoulement through time, pending the obtaining of durable solutions." GOODWIN-GILL, supra note 56, at 123.

${ }^{133}$ International Covenant on Civil and Political Rights, supra note 46, Art. 12(2).
} 
in the Refugee Convention, the principle of family unity was referred to in the Final Act of the United Nations Conference of Plenipotentiaries on the Status of Refugees and Stateless Persons, which drafted the Convention, ${ }^{134}$ and the UNHCR Executive Committee has adopted several conclusions affirming its importance. ${ }^{185}$ Australia assumed legal obligations to respect the family under the International Covenant on Civil and Political Rights and the Convention on the Rights of the Child, which may require the reunion of families separated in the course of a refugee's flight.

Relevant provisions of the Covenant on Civil and Political Rights are Articles 23 and 17 concerning the right to marry and to found a family, and prohibiting arbitrary interference in family life, respectively. The Human Rights Committee has stated that Article 23 implies the possibility that couples will live together, which requires reunification of families "when their members are separated for political, economic or similar reasons." ${ }^{136}$ Furthermore, the Committee stated in its general comment on the position of aliens under the Covenant that although there is no right to enter a country other than the state of nationality, exceptions arise in cases involving considerations of family life ${ }^{137}$ Recently, the Committee decided that Australia would be in breach of Articles 17, 23, and 24 (protection of children) of the Covenant if it deported the stateless parents of a child born in, and a citizen of, Australia, both of whom had resided there (albeit unlawfully) for many years. ${ }^{138}$

The jurisprudence of the Human Rights Committee is supported by developments before the European Court of Human Rights regarding Article 8 of the European Convention for the Protection of Human Rights and Fundamental Freedoms, ${ }^{139}$ and the Court could conceivably hold that family members of a refugee have a right to enter the state to which the person has fled if it is otherwise impossible to reestablish family life ${ }^{140}$ Most recently, the summary conclusions of the fourth expert roundtable, which formed the "second track" of the "global consultations" held by UNHCR in the context of the fiftieth anniversary of the Refugee Convention, accepted that a right to family reunion may be recognized in such cases. ${ }^{141}$ These conclusions constitute subsidiary evidence as to the state of international law. ${ }^{142}$

The Convention on the Rights of the Child also contains various relevant provisions, including Article 16 (the equivalent of Article 17 of the International Covenant on Civil and Political Rights); Article 3, which states the cardinal principle of the "best interests" of the child; Article 22 concerning refugee children; and Articles 9 and 10, which deal with the separation of children from parents. Article 22(2) requires states to assist refugee children

\footnotetext{
${ }^{134}$ Conference of Plenipotentiaries on the Status of Refugees and Stateless Persons, Final Act, Recommendation B (July 28, 1951).

${ }^{135}$ UNHCR Executive Committee, Conclusions No. 88 (L), Protection of the Refugee's Family (1999); No. 85, supra note 58, paras. (u)-(x); No. 84 (XLVIII), Refugee Children and Adolescents (1997); No. 24 (XXXII), Family Reunification (1981); No. 9 (XXVIII), Family Reunion (1977); No. 1 (XXVI), Establishment of the Sub-Committee and General, para. (f) (1975).

${ }^{136}$ Human Rights Committee, General Comment No. 19, para. 5 (July 27, 1990), reprinted in CoMPILATION OF GENERAL COMMENTS AND GENERAL RECOMMENDATIONS ADOPTED BYHUMAN RIGHTS TREATY BODIES, UN DOC. HRI/ GEN1/Rev.5, at 137, 138 (2001), available at <http://www.unhchr.ch/tbs/doc.nsf> .

${ }^{137}$ Human Rights Committee, General Comment No. 15, para. 5 (Apr. 11, 1986), reprinted in id. at 127, 128, available at <http://www.unhchr.ch/tbs/doc.nsf >.

${ }^{138}$ Communication No. 930/2000, Hendrik Winata \&c So Lan Li v. Australia, UN Doc. CCPR/C/72/D/930/ 2000 (2001), available at <http://www.unhchr.ch/tbs/doc.nsf>.

${ }^{139}$ European Convention for the Protection of Human Rights and Fundamental Freedoms, supra note 83, as amended by Protocol No. 11, May 11, 1994, 33 ILM 943 (1994).

${ }^{140}$ See Kate Jastram \& Kathleen Newland, Family Unity and Refugee Protection 28, background paper for discussion at the UNHCR global consultations (2001), at <http://www.unhcr.ch/cgi-bin/texis/vtx/home?page=events >; cf. Hélène Lambert, The European Court of Human Rights and the Right of Refugees and Other Persons in Need of Protection to Family Reunion, 11 INT'L J. REFUGEE L. 427, 438 (1999).

${ }^{141}$ UNHCR and Graduate Institute of International Studies in Geneva, Geneva Expert Roundtable, Summary Conclusions on Family Unity, para. 5 (Nov. 8-9, 2001), at <http://www.unhcr.ch/cgi-bin/texis/vtx/home?page=events $>$.

142 Many of the participants are eminent publicists within the meaning of Article 38(1) (d) of the Statute of the International Court of Justice. Some members of the roundtables, however, participated as governmental representatives rather than independent experts.
} 
in tracing their parents and gaining information necessary for family reunion. The view was expressed during the drafting process that states should not be obliged to guarantee the admission of family members of child refugees and asylum seekers. ${ }^{143}$ However, Article 22 simply reinforces other obligations that may require reunion, including Articles 17 and 23 of the Covenant on Civil and Political Rights.

Article 9 (1) of the Convention on the Rights of the Child prohibits the separation of parents from their children unless it is in the best interests of the child. The travaux préparatoires indicate that Article 9 was intended to apply to separations occurring in the domestic context, leaving separations involving different countries to be regulated by Article $10 .{ }^{144} \mathrm{How}-$ ever, the two articles are expressly and closely linked. Article $10(1)$ provides that, "[i]n accordance with the obligation of States Parties under article 9, paragraph 1, applications by a child or his or her parents to enter or leave a State Party for the purpose of family reunification shall be dealt with by States Parties in a positive, humane and expeditious manner." 145 As noted during the drafting of Article 10, the obligation to deal with applications in a "positive" manner does not prejudge the outcome of the application. ${ }^{146}$ However, the new Australian visas preclude the possibility of an application altogether. ${ }^{147}$

\section{CONCLUSION: WHitheR THE PACIFIC SOLUTION?}

The Pacific Solution is detrimental to refugee protection and likely to prove impractical in the longer term. ${ }^{148}$ The Australian government has erected the main obstacles to change through its unwillingness to listen to international opinion ${ }^{149}$ and its corresponding eagerness to manipulate Australian public opinion. Onshore asylum seekers are portrayed as "forumshoppers" who throw their children overboard, ${ }^{150}$ and terrorists. ${ }^{151}$ By playing into Australians' long-standing fear of the Asian other, ${ }^{152}$ the government secured election for a third term. It now thinks it has a mandate for its policies.

PENELOPE MATHEW*

\footnotetext{
${ }^{143}$ SHARON DETRICK, A COMMENTARY ON THE UNITED NATIONS CONVENTION ON THE Rights OF THE CHILD 371 (1999).

${ }^{144} I d$. at 170.

${ }^{145}$ Convention on the Rights of the Child, supra note 48, Art. 10(1) (emphasis supplied).

${ }^{146}$ UN Doc. E/CN.4/L.1575, para. 74 (1981), cited in DETRICK, supra note 143, at 192 n.56.

${ }^{147}$ Australia has previously been criticized concerning family reunion for refugee children. Concluding Observations of the Committee on the Rights of the Child: Australia, UN Doc. CRC/C/15/Add.79, para. 30 (1997), available at <http://www.unhchr.ch/tbs/doc.nsf $>$.

${ }^{148}$ Only Ireland has shown any interest in resettling the asylum seekers. Andrew Clennell, Refugee Plan May Backfire, Says Ruddock, SYDNEY MORNING HERALD, Dec. 6, 2001, available at <http://old.smh.com.au/news/0112/06/ national/national5.html>.

${ }^{149}$ This is evidenced by Australia's failure to amend its legislation in response to the Human Rights Committee's views in A v. Australia, supra note 48, and strong advocacy of the Pacific Solution by the minister for immigration, see, e.g., Ruddock, supra note 95.

${ }^{150}$ It was alleged in the lead-up to the recent federal election that some boat people had thrown children into the sea. Apparently, there was no evidence to support this statement and the Senate has established a "select committee for an inquiry into a certain maritime incident."

${ }^{151}$ See AAP, Blast for Reith on Terrorism, AGE, Sept. 15, 2001, available at $<\mathrm{http}: / /$ www.theage.com.au/news/national/ 2001/09/15/FFX1PUKMLRC.html>.

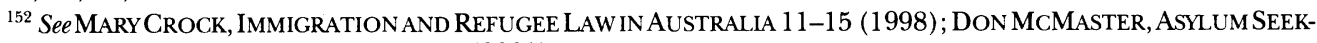
ERS: AUSTRALIA's RESPONSE TO REFUGEES (2001).

* Senior Lecturer, Faculty of Law, Australian National University. This article draws on an opinion written by the author at the request of the United Nations High Commissioner for Refugees. I am grateful for the assistance of Marie-Charlotte McKenna and Andrei Seeto.
} 